\title{
EVALUATION OF THE RESISTANCE OF THE MITE Varroa destructor TO THE AMITRAZ IN COLONIES OF HONEY BEES (Apis mellifera) IN ALGERIA
}

\author{
Cezayir'de Bal Arısı (Apis mellifera) Kolonilerinde Akarın (Varroa destructor) \\ Amitraz'a Direncinin Değerlendirilmesi \\ (Genişletilmiş Özet Makalenin Sonunda Verilmiştir)
}

Noureddine ADJLANE ${ }^{1^{*}}$, Nizar HADDAD ${ }^{2}$

\author{
${ }^{1}$ Département de Biologie, Université M'hamed Bougara, Avenue de l'indépendance \\ Boumerdes, 35000 Algérie. Laboratoire de Biologie et de physiologie animale, ENS kouba Algérie \\ ${ }^{2}$ Bee Research Department, National Center for Agricultural Research and Extension, \\ P.O.Box 639-Baqa' 19381, Jordan \\ *Corresponding author: adjlanenoureddine@hotmail.com \\ Geliş Tarihi: 16.04.2017 Kabul Tarihi: 29.06.2017
}

\begin{abstract}
Varroa mite has become a major concern of beekeepers in Algeria since the discovery of the first cases of infestation in the year 1982. Amitraz is the predominant compound used in Algeria to control $V$. destructor, its constant application has caused the appearance of resistant mite populations to this product in several parts of the world. This study was conducted to detect the possible existence of populations of resistant mites to Amitraz in Algeria. To determine the mites mortality percentage to the Amitraz, they were exposed to a trips of $2.5 \times 1.0 \mathrm{~cm}$. Varroa mortality in apiaries treated with Amitraz was $39.23 \%$, lower than the $87.40 \%$ mortality obtained in apiaries that only received an alternative treatment. A significant difference $(P>0.05)$ was found between two mortality of Varroa. Our results indicate a possible occurrence of Varroa resistance to Amitraz. The introduction of integrated programs for resistance management is required.
\end{abstract}

Keywords: Amitraz, Varroa destructor, Resistance, Algeria.

\section{ÖZ}

Varrao akarı 1982 yılındaki ilk bulaşımın öğrenilmesinden sonra Cezayir'de arıcılar içn önemli bir ilgi konusu olmuştur. Amitraz varroa için Cezayir'de sürekli kullanılan ana kimyasal olduğundan dünyanın bir çok yerinde olduğu gibi direnç gelişimine neden olmuştur. Bu çalışma Cezayir'de Amitraz'a karşı akar populasyonlarının olabilecek direnç geliştirmesini araştırmak için yapılmıştır. Varroa ölümü sadece Amitraz kullanılan arılıklarda \% 39.23 olurken ikinci bir alternative tedavi kullanılan arılıklarda ise \% 87.40 olmuştur. İki varroa ölüm durumları arasında önemli bir fark $(P>0.05)$ bulunmuştur. Bu sonuçlar Varroa'nın Amitraz'a olabilecek bir direnç kazandığını göstermektedir. Bu durumda birleşik direnç yönetim programı uygulanması gerekli görülmüştür.

Anahtar Kelimeler: Amitraz, Varroa destructor, Direnç, Cezayir 


\section{ARAŞTIRMA MAKALESI / RESEARCH ARTICLE}

\section{INTRODUCTION}

Honey bees, Apis mellifera (L.) are important agricultural assets, both for the direct production of commoditiessuch as honey and beeswax, and for vital pollination services provided to support a wide range of wild and cultivated crops (Klein et al. 2007). The mites (Acari) that parasitize honey bees have become a global problem is one of the most serious diseases of honey bees (Apis mellifera). Varroa destructor mites are considered to be the reason for CCD (Colony Collapse Disorder). Varroa mites feed on the developing honey bee larvae, pupae and on the adult bees. Heavily infested colonies usually have large numbers of unsealed brood cells. Dead or dying newly emerged bees with malformed wings, legs, abdomen and thorax present at the entrance of affected colonies and heavily infected colonies produce little or no honey (Ritter, 1981).

Varroa disease is a parasitic disease of adult bees and brood, caused by an external parasitic mite, Varroa destructor (Anderson and Trueman, 2000); it is the most important parasite of Apis mellifera that influences the colony development and performance (Ball, 2003), and is considered as the most serious problem of the beekeeping industry worldwide (Haddad et al., 2007; Guzman-Novoa et al., 2010; Di Prisco et al., 2011; Adjlane et al., 2012). Parasitism of the bee by this mite causes deformation and weakness of the young workers. Heavy infestation causes death before the emergence of nymphs and the birth of mutilated bees (Boecking and Genersch, 2008). Varroa heavily decrease the general weight up to $30 \%$ of individuals (Bowen-Walker and Gunn, 2001), the total hemolymph volume and its protein content (Bowen-Walker et al., 1999). It was estimated to be between $10 \%$ and $50 \%$ reduction in total protein of parasitized nymphs (Dandeu et al., 1991). Infestation with the mite leads to quantitative andqualitative changes in hemolymph. Weinberg and Madel (1995) report that 1-3 mites feeding on a worker bee pupa cause a reduction in the host's hemolymphvolume by $23.6 \%$; in the case of a drone pupa, thevolume of hemolymph decreases by $18.2 \%$, onaverage. V.destructor is responsible for the transmission of viruses to their hosts (Rosenkranz et al., 2010). Varroosis is a highincidence parasitic pathology, affecting colonies of Apis mellifera L. Varroosis causes serious production losses, both global and locally, as it weakens hives and leads to bee's death (Webster and Delaplane, 2001).

Different active ingredients (e.g. coumaphos, amitraz, bromopropylate, cymiazole, fluvalinate, flumethrin, etc) and substrates (e.g. plastic and cardboard strips, gels and sponges) (Webster and Delaplane, 2001) have been used to control varroosis. Amitraz acts on the target pestspecies interacting with the octopamine receptor of the central nervous system and is known as neurotoxic, sub-lethal miticide (Evans and Gee, 1980).

Amitraz (formamidine) has been also used for V.destructor control worldwide, and mite resistance to this acaricide was reported, too, although few cases were reported (Rodriguez-Dehaibes et al., 2005; Semkiw et al., 2013). Several chemical substances were used successfully to control mites, in recent years, resistance to acaricides has become a major problem in the control of varroa. Varroa destructor strains have been reported to be resistant to fluvalinate and flumethrin (Baxter et al., 1998), coumaphos (Spreafico et al., 2001), and to amitraz, (Elzen et al., 2000a).

The concept of resistance to natural toxins that is observed in animals is defined as the ability of the organism to tolerate a substance in toxic doses that may be lethal to most specimens in an ordinary population of the same species (Watkins, 1996). The ability of mites to develop drug resistance is believed to be at the root of a lower effectiveness of acaricides (Mathieu et Faucon, 2000). The objective of the research presented in this paper was to evaluate the efficacy of amitraz used as the contact varroacide (Apivar) to control V.destructor in the honeybee colonies.

\section{MATERIALS AND METHODS}

Field experiment was initiated in July 2015 in 4 apiaries where the amitaz was applied in a continuous way for a period of 3 years for the control of V.destructor (Algeries), and 4 apiaries where some alternative method was applied (oxalic acid, fluvaliante, thymol) for a period of similar time (Blida), taking 20 colonies for each apiary.

The method of Elzen et al., (1999) was used to assess resistance levels in the eight apiaries. The assay was conducted as follows. Cut a $9 \mathrm{~mm}$ by $25 \mathrm{~mm}$ strip from an apivar strip and staple it to the centre of an index card. Place the card in a $500 \mathrm{ml}$ 


\section{ARAŞTIRMA MAKALESI / RESEARCH ARTICLE}

jar with the strip facing inwards. Prepare a 2-3mm light metal mesh cover for the jar. Collect samples of 150 bees from each hive, place them in the jar, place a sugar cube in the jar and cover it with the mesh lid. Store upturned in the dark, at room temperature. After 24 hours, hit the upturned jar with your palm three times over white paper. Count the dislodged mites and place the upturned jar in a freezer until the bees are dead (4hrs). Count the remaining mites. Percent mortality was calculated as (number of mites killed in $24 \mathrm{~h} /$ total mites in the jar) $\times 100$.

The data obtained was analysed with Statistical software version 5.0 using analysis of variance (ANOVA).

\section{RESULTS}

The results of the treatments carried out on the eight apiaries are indicated in Figure 1. The average efficacy of the treatment with fluvalinate in Algiers was $39,23 \%$. In the region of Blida, the efficacy of the treatments was $87,40 \%$. Significantly lower mite mortality was observed in Algriescompared to the other apiaries in Blida. The analyses of variance showed no difference in effectiveness $(P>0.0)$ among the three apiaries of Algries and Blida.

Our results indicate a possible occurrence of varroa resistance to amitraz. The reduction in the effectiveness is due to the continuous and inadequate use of the amitraz, because some beekeepers do not remove the plastic ribbons of Apivar ${ }^{\circledR}$, which should only remain for six weeks inside the beehive. However, these ribbons of the product usually remain around one year inside of the beehives; therefore the mites are exposed to smaller dose to those recommended.

Figure 1. Percentage of Varroa mortality obtained with the amitraz application (letters indicate significant differences between treatments $(P<0.01)$.

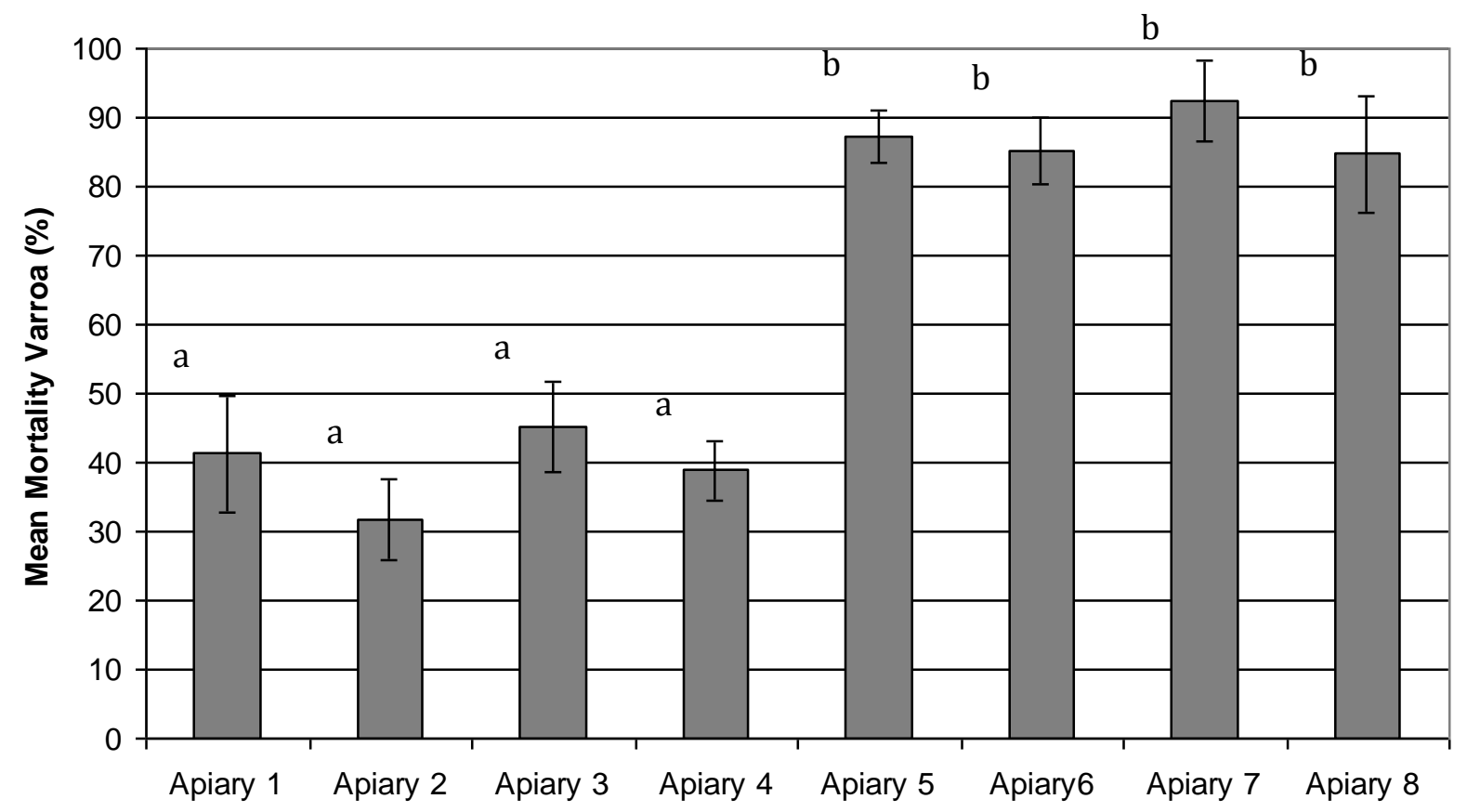

Apiray 1, 2, 3 and 4 : location of Algries

Apiary 5, 6, 7 and 8: location of Blida 


\section{ARAŞTIRMA MAKALESI / RESEARCH ARTICLE}

\section{DISCUSSION}

The mites populations resistance to amitraz was also confirmed in the USA, Italy, Portugal, Argentina, Mexico and France (Elzen et al, 1999; Milani, 1999; Elzen et al., 2000; Mathieu and Faucon, 2000; Pires etal., 2005; RodríguezDehaibes et al., 2005; Maggi et al., 2010).

Floris et al. (2001) found that the efficacy of amitraz in plasticstrips against $V$. destructor in colonies with broodwas only $74.90 \pm 5.90 \%$.

Resistance of mites to Apivar has been reported inMinnesota and other areas in the United States ofAmerica (Elzen et al., 2000). In 17\% of the colonies examined in Portugal, the Apivar efficacy did not exceed $60.1 \%$ (Pires et al., 2007).In a field test in eastern Algeria, Loucif-Ayad et al (2010) recorded a very low efficiency for Apiar (82-88\%).

Elzen and Westervelt (2002) reported the first case of resistance of varroa to coumaphos in Florida after only 4 years of use as a varroa treatment. Varroa destructor resistance to amitraz has been described by several authors (Elzen et al., 1999; Mathieu and Falcon 2000; Rodriguez-Dehaibes et al., 2005). Floris et al., (2001) have found 75\% efficacy using amitraz in Italy. Faucon et al. (2007) conclude that Apivar ND preserved treated colonies against $99,5 \%$ of the population found in control colonies. The tests carried out in Ghazvin in Iran against Varroa destructor showed a good effectiveness, of Apivar $\AA 96.68 \%$, for Bayvarol ${ }^{\circledR}$ 96,59\% (Shahrouzi 2009). Marinelli et al., (2002) also used Apivar® and obtained an average efficiency of $67 \%$ Migratory apiary managementconstitutes an additional factor contributing to theproliferation of resistant Varroa mites.

Marinelli et al., (2002) noted the operational and climatic conditions of central Italy where the acaricide was evaluated may have had some effect on amitraz management and therefore may be the cause of discrepancies in the results. Resistance is not limited to the Amitraz varroacides, it has also been reported for coumaphos in Italy (Abed and Ducos de Lahitte, 1993; Milani and Della Vedoiva, 1996; Spreafico et al., 2001). Resistant genotypes usually are at some fitness disadvantage in the absence of pesticides (Denholm and Rowland, 1992), because of unbalanced or unregulated physiological processes. This makes the frequency of resistant mites decline when the acaricide is not used (a phenomenon usually called reversion).

According to Sammataro et al. (2005), the presence of resistant mites (in colonies where no strong acaricides pressures are obvious) may be due to (1) bees robbing honey from a weak or dying hive (with resistant mites) within the flight range of the apiary and, as a consequence, acquiring those mites; (2) introduction of packaged bees and queens from other states already parasitized by resistant mites; or (3) drifting bees, a common phenomenon in large apiaries where phoretic mites can be swiftly distributed throughout the whole apiary in a short time.

\section{Conclusion}

In apiaries where Varroa mites are resistant, the introduction of integrated programs for resistance management is required. This includes the selection of mite-tolerant bees, monitoring of mite populations, nonchemical control methods, and pesticides rotation, whether natural or synthesized.

\section{Acknowledgements}

The authors thank the Association of Beekeepers Mitidja-Blida and especially Mr. Hocine Diffalah and Hamzaoui Mohammed for its material and technical support during this study.

\section{REFERENCES}

Adjlane, N., Doumandji, S.E. and Haddad, N. 2012. Situation de l'apiculture en Algérie: facteurs menaçant la survie des colonies d'abeilles locales Apis mellifera intermissa. Cah Agric, 21: 235-241; doi: 10.1684/agr.2012.0566.

Anderson DL, Trueman JWH 2000. Varroa jacobsoni (Acari: Varroidae) is more than one species. Exp Appl Acarol. 24: 165-189.

Ball, B.V. (1993). The damaging effects of Varroa jacobsoni, pp. 9-16. In: A. Matheson (Ed.). Living Varroa, Ed. Internati. Bee res. Associate., Cardiff, 325 p.

Boecking, O. and Genersch, E. 2008. Varroosisthe ongoing crisis in beekeeping. J. Verbr.

Bowen-Walker PL, Martin SJ, Gunn A (1999) The transmission of Deformed Wing Virus.

Bowen-Walker, P.L. and Gunn, A. 2001. The effect of the ectoparasitic mite, Varroa destructor on adult worker honeybee (Apis mellifera) emergence weights, water, protein, 


\section{ARAŞTIRMA MAKALESI / RESEARCH ARTICLE}

carbohydrate, and lipid levels. Entomol. Exp. Appl., 101 (3): 101-112.

Dandeu JP, Lux M, Colin ME, Rabillon J, David B 1991. Étude immuno-chimique de l'hémolymphe d'abeille ouvrière adulte (Apis mellifera L) saine ou infestée par Varroa jacobsoni Oud. Apido. 22: 37-42.

Di Prisco G., Pennacchio F., Caprio E., Boncristiani HF JR., Evans JD., Chen Y., 2011 - Varroa destructor is an effective vector of Israeli acute paralysis virus in the honeybee, Apismellifera. J. Gen. Virol., 92: 151 - 155.

Elzen, P. J., Baxter, J. R., Spivak, M., \& Wilson, W. I. 2000. Control of Varroa jacobsoni Oud. resistant to fluvalinate and amitraz using coumaphos. Apidologie, 31, 437-44.

Floris, I., Satta, A., Garau, V.L., Melis, M., Cabras, P. \& Aloul, N., 2001. Effectiveness, persistence, and residue of amitraz plastic strips in the apiary control of Varroa destructor. Apidologie 32: 577-585.

Guzman-Novoa, E., Eccles, L., Calvete, Y., Mcgowen, J., Kelly, P.G., and Corra-Benitez, A. 2010. Varroa destructor is the main culprit for the death and reduced populations of overwintered honey bee (Apis mellifera) colonies in Ontario, Canada. Apidologie, 41: 443-450.

Haddad, N., Evans, J., Pettis, J., and Migdali, H. 2007. Genetic structure of Varroa mite populations in $A$. mellifera syriaca. Advances in Environmental Biology, 1 (1): 1-3.

Higes Pascual, M. 1999. Ensayo de campo de la eficacia del Apivar ${ }^{\circledR}$ y la rotenona en el control de la varroasis de la abeja de miel. Apiacta, 34:33-38.

Klein, A.-M., B. E. Vaissiere, J. H. Cane, I. SteffanDewenter, S. A. Cunningham, C. Kremen, and T. Tscharntke. 2007. Importance of pollinators in changing landscapes for

Loucif-ayad, W., Aribi N., Smagghe, G., Soltani, N., 2010. Comparative effectiveness of some acaricides used to control Varroa destructor (Mesostigmata: Varroidae) in Algeria African Entomology 18(2): 259-266.

Maggi M. D., Ruffinengo S. R., Negri P., Eguaras M. J. 2010. Resistance phenomena to amitraz from populations of the ectoparasitic mite Varroa destructor of Argentina. Parasitol. Res.,
107(5): 1189-92. DOI: 10.1007/s00436-0101986-8.

Marinelli, E.; De Pace, F.M.; Ricci, L. 2002. Efficacia di Apivar per il controllo della varroa. Nota preliminare. Apitalia, 4: 45-49.

Mathieu L., Faucon J. P. 2000. Changes in the response time for Varroa jacobsoni; exposed to amitraz. J. Apic. Res.; 39(3-4): 155-158.

Milani N. 1999. The resistance of Varroa jacobsoni Oud. to acaricides. Apidologie, (1), 15-22.

Pires S., Murilhas A., Pereira O., Maia M. 2005. Current effectiveness of amitraz against Varroa in Portugal. In Proceedings of 39th Apimondia International Apicultural Congress, Dublin, Irlandia, 2005: 78.

Pires S., Pereira Ó., Murilhas A. 2007. Field and laboratory testing for amitraz-tolerant varroa populations. How comparable are their results? In Proceedings of 40th Apimondia International Apicultural Congress. Melbourne,

Ritter, W. 1981. Varroa disease of honeybee Apis mellifera. Bee World, 62:141-153.

Rodríguez-Dehaibes, S., G. Otero-Colina, V. Sedas and J. Jiménez. 2005. Resistance to amitraz and $\mathrm{fl}$ umethrin in Varroa destructor populations from Veracruz, México. Journal of Apicultural Research, 44: 124-125.

Rosenkranz P, Aumeier P, Ziegelmann B, 2010. Biology and control of Varroa destructor. J Invertebr Pathol 103: S96-S119

Watkins M.: Resistance and its relevance to beekeeping. Bee World 1996, 78

WEBSTER, T. C.; DELAPLANE, K.S. (Eds.). 2001. Mites of the honey bee. Dadant \& Sons, Hamilton, IL, USA. $280 \mathrm{p}$.

Weinberg K. P., Madel G.: The influence of the mite Varroa jacobsoni Oud. On world crops. Proc. R. Soc. B. 274: 303-313.

\section{GENIŞLETILMIŞ ÖZET}

Bal arıları hem arı ürünleri ve hem de tozlaşma ile sağaldığı katkılardan dolayı önemli bir konu olarak dünyada ilgi alanı içindedir. Bal arısı kolonilerinde hem ölümlere ve hemde ürün kaybına nedne olan en önemli faktör olarak varroa akarı karşımız çıkmaktadır. Bu yüzden varrao akarına karşı çok çeşitli tedavi ve ilaçlar kullanılmaktadır. Bu ilaçlardan Amitraz (formamidine) octopamine 


\section{ARAŞTIRMA MAKALESI / RESEARCH ARTICLE}

alıcına bağlanarak nörotoksik etki gösteren bir yapıya sahiptir. Amitraz dünyada yaygın olarak kullanldığından son yıllarda bu akar ilacına karşı direnç mekanizması rapor edilmiştir. Bazı varroa hatları için ise fluvalinate, flumethrin, coumaphos'a karşı ilaç dirençleri de rapor edilmiştir.

Varroa akarı 1982 yılındaki ilk bulaşımın öğrenilmesinden sonra Cezayir'de arıcılar için önemli bir ilgi konusu olmuştur. Amitraz varroa için Cezayir'de sürekli kullanılan ana kimyasal olduğundan dünyanın bir çok yerinde olduğu gibi direnç gelişimine neden olmuştur. Bu çalışma Cezayir'de Amitraz'a karşı akar populasyonlarının olabilecek direnç geliştirmesini araştırmak için yapılmıştır.
Bu çalışma 2015 Temmuz ayında başlatılmış ve Cezayir'de 4 arılıkta sürekli 3 yıl boyunca Algeries bölgesinde yapılmıştır. Blida bölgesinde 4 arılıkta ise alternative tedavi okzalik asit, timol ve fluvaliante aynı süre için ayrılan zamanda her arılıktan alınan 20 kolonide kullanılmıştır.

Varroa ölümü sadece Amitraz kullanılan arılıklarda Algerias bölgesinde \% 39.23 olurken ikinci bir alternative tedavi kullanılan Blida bölgesindeki arılıklarda ise \% 87.40 olmuştur. İki varroa ölüm durumları arasında önemli bir fark $(P>0.05)$ bulunmuştur. Bu sonuçlar Varroa'nın Amitraz'a olabilecek bir direnç kazandığını göstermektedir. Bu durumda birleşik direnç yönetim programı uygulanması gerekli görülmüştür. 